\title{
THE MORPHOLOGICAL ANALYSIS BETWEEN BACK FORMATION AND CLIPPING ON TREASURE ISLAND NOVEL
}

\author{
Sisca Fitriana ${ }^{1}$, Ida Lisdawati ${ }^{2}$ \\ ${ }^{1}$ IKIP Siliwangi \\ ${ }^{2}$ IKIP Siliwangi \\ ${ }^{1}$ sisca.fitriana1203@gmail.com, ${ }^{2}$ idalisdawati9088@ gmail.com²
}

\begin{abstract}
This study aims to analyze the use of clipping and back formation in a novel titled Treasure Island Novel by Robert Louis Stevenson. The subject of this research is to focus on the introduction of the characters involved in this novel. The novel tells from a first-person perspective that Robert Louis Stevenson is Jim, who takes many important decisions. Other characters in this story are Squire Trelawney, Doctor Livesey, an old captain named Billy Bones, Long John Silver who has a cruel character and Black Dog captain, a blind pew and his gang. This research was conducted using descriptive quantitative methods and to process data using the frequency formula from the Guttman theory frequency. The findings of the analysis showed that the clipping frequency was $79,63 \%$ and the back formation frequency was $20,37 \%$. The results show that in the Treasure Island Novel clipping the most dominant appeared. In the novel there are 54 sentences included in clipping and back formation, 43 sentences included in clipping and 11 sentences included in back formation. Robert Louis Stevenson in writing the Treasure Island Novel is only small part of the word that uses the process of cutting or reducing words called the process of clipping and back formation. The word that appears most in clipping is Bill (Billy Bone) and in back formation is mate (soulmate).
\end{abstract}

Keywords: Back Formation, Clipping, Morphosyntax, Word Formation

\section{INTRODUCTION}

In this modern era, the young generation has developed and it gave the big effect to their language and literature. They refers to use the word that easy ones to speak and informal daily, such as cutting the part of these basic word, but it do not not change the real meaning applied. The cutting of word part is known as a slang word. One of slang word can also be in the form of word condensation with delete the part of these word.

Likewise in Indonesia, the intensification os western culture entering Indonesia has made the wider understanding of the community about English language. It is also a very active role for the young generation of Indonesia as active recipients of western culture, more precisely in the use of English language. Many young people in Indonesia use English language in their daily lives. For example is slang word that come from the western culture they used to use that are starting to influence the young generation of Indonesia. Slang word has the meaning of using words by cutting or eliminating parts of basic word used to make it shorter. The use of English language is obtained not only from formal education but from informal as well. They know these words usually from cyberspace such as social media. They also usually get words that include the slang word from a reading, for example from articles, novels or comics. But only a few of them find it in articles, novels or comics because their interest in reading is still lacking. 
Indonesia's young generation has low interest in reading. It can be proved by their addiction on gadget. They will choose play their gadgets for playing or opening their social media. Other factors also affect the lack of interest in reading, which has not yet begun reading habits to yourself, lack of motivation from the surrounding environment and laziness to read and develop the main idea in the text is rerad. Even though with reading we can get insight very wide and help appreciate masterpiece other peopld has been made. Nowdays, it is very rare to find young generation that still fonding to read a book and it is very important to keep to increase young generation awareness the importance of reading; keep trying so that reading interest of young generation should not became extinct because with increase reading interest of young generation will give positive impact for writer.

The study of language and all event which related its language called linguistic. Some part of linguistic dealing with words internal structure and word formation through morpheme and sentence construction that called morphosyntax. It explains how word parts are arranged from the correct sentence based on the class word and the function.

Morpho-syntax came from mohorpology and syntax. Morphology is the study about word structure (1993) and syntax is the study about sentence structure (2011) as cited in (Ayu Indah Maha Dewi et al., 2018). The study that combine of morphology and syntax is called morphosyntax. Another expert also explain, morphology is about how these words be explain into elements that have the meaning the smaller one (2007) and syntax is the study about sentence and the structure as cited in (Rosiana, 2018). They interconnected because indeed their have relation is very close, so syntax explains how the words arranged of a sentence and morphology is how form these words.

In Morphosyntax, there are processes of form the words called word formation. Word formation is the study the way complex words that a new from other basic word (Nuraeni, 2018). Word formation is the process make a new word with add a suffix or prefix of basic word so that giving a new meaning. Other expert explain that word formation is create a new word with combining morpheme or change that morpheme (Mainingrum, 2018). The process of word formation that increases prefix odr suffix in one basic word will give a new meaning. There are many types of word formation, that is coinage, borrowing, compounding, blending, clipping, back formation, conversion, acronym, derivation, prefix and suffix and multiple process (2003) as cited in (Mandala, 2018).

Back formation and clipping which is parts of word formation. Back formation process occurs when there is removal of affixes from morpheme (Mainingrum, 2018) and it changes category and makes a new word. Back formation can also be interpreted with process word formation in a part difference language (Carlos et al., 2019). It means back formation is cut of the word to be shorter from a long word, or back formation is conclude a word from a short word from a long word (Valiyeva, 2019). Back formation can also defined as the way where the new word formed from another basic word. It uses an analogy for making from the word similar ones with the words is already in the language.

Clipping is the process of cutting a word so that the word become a short (Nasser, 2018). Generally, clipping is also considered as a phenomenom which consists of the process cutting or removing parts of the basic word so that it produces words that are shorter then the previous word or lost material from the word. The process from formed a new word with cut off some part from basic word be shorter both at the beginning, middle, of the end or a combination is called clipping (Mainingrum, 2018). Clipping can also defined as a process form the new word with relieve syllables of basic word, like a phone from thelepon selular. Clipping also has a 
meaning deleting some part of word from make be shorter (Multazim \& Nurdin, 2019). Truncated form of the basic word have the same meaning with the initial word but more considered not formal. With another meaning, clipping is process formed the word with cut off these word can begin or end of these word (Jayaputri, 2018). The word is made with clipping process usually formed into one syllable. Other experts also explained that clipping is a process word formation where a basic word reduced or shortener but not change the real meaning (Rizki \& Marlina, 2018). Clipping is also cut off one of part from basic word (Valiyeva, 2019). Clipping also makes it easier for users to spell and use it, so it can be concluded that clipping is a process create a new syllable with cut off one or more syllable from existing basic word (Harared, 2018).

Based on the theory above, this research focuses on "the morphological analysis between back formation and clipping on treasure island novel" because it will discuss and find the back formation and clipping on treasure island novel to prove that the writer chooses the words that is easy to use and simple, but it has same the meaning of basic word that will to use and introduces the word formation and clipping as word formation to the readers.

\section{METHOD}

The method that is used in this research is descriptive quantitative analysis. Quantitative research is a research process based on deductive thory that focuses on the theory of submission and research hypotheses that find relationships or compare using numerical data and statistical methods to infer specially about research results (Kaswan et al., 2016). That means to explain the data obtained with describing the phenomena under investigation.

In this research, the researcher observed the novel that the title is Treasure Island by Robert Louis Stevenson. The research analysis the words in the Treasure Island novel by Robert Louis Stevenson to find out the word formation used in that novel. The researcher focus to analyzed the Trasure Island novel by Robert Louis Stevenson that used back formation and clipping that the part of word formation. The data in this research is Robert Louis Stevenson's novel entitled Treasure Island. The researcher took to analyzing that novel because it was to increase interest in reading which was still lacking. After taking the novel from internet, the researcher start reading the novel. Next the researcher find out the words that are include in clipping and back formation in each sentence. After finding the clipping and back formation, the researcher make a table that divides between clipping and back formation along with the sentence used.

After that, the researcher calculate the data with frequency formula. the calculation of the data obtained by researchers is based on Guttman theory frequency so it needs to be processed in obtained to arrive at conclusions in the form of percentage to determine the dominant clipping or back formation. A percentage is obtained by dividing the number of frequencies found with number of samples then multiplied with 100 . The formula of Guttman theory frequency is:

After that, the researcher making conclusion.

$$
\mathrm{P}=\frac{F}{N} \times 100
$$

\section{RESULTS AND DISCUSSION}

\section{Results}

Analysis results show that back formation and clipping are more dominant clipping. These results can be seen in table 1 .

Table 1. Data Clipping and Back Formation on Treasure Island Novel 


\begin{tabular}{|c|c|c|c|}
\hline Chapter/Page & Sentence & $\begin{array}{c}\text { Back } \\
\text { Formation }\end{array}$ & Clipping \\
\hline $1 / 5$ & $\underline{\text { Dr. }}$ Livesey, & & Doctor \\
\hline $1 / 9$ & $\underline{\operatorname{sing}}$ & Singer & \\
\hline $1 / 11$ & $\underline{D r}$. & & Doctor \\
\hline $1 / 12$ & $\underline{D r}$. & & Doctor \\
\hline $1 / 14$ & $\underline{D r_{.}}$. & & Doctor \\
\hline $2 / 16$ & $\underline{D r}$. & & Doctor \\
\hline $2 / 16$ & Bill? & & $\begin{array}{l}\text { Billy } \\
\text { Bone }\end{array}$ \\
\hline $2 / 17$ & $\underline{B i l l}$ & & $\begin{array}{l}\text { Billy } \\
\text { Bone }\end{array}$ \\
\hline $2 / 17$ & mate & Soulmate & \\
\hline $2 / 17$ & $\underline{\text { Bill }}$ & & $\begin{array}{l}\text { Billy } \\
\text { Bone }\end{array}$ \\
\hline $2 / 17$ & mate & Soulmate & \\
\hline $2 / 17$ & $\underline{\text { Bill. }}$. & & $\begin{array}{l}\text { Billy } \\
\text { Bone }\end{array}$ \\
\hline $2 / 18$ & $\underline{\text { Bill, }}$, & & $\begin{array}{l}\text { Billy } \\
\text { Bone }\end{array}$ \\
\hline $2 / 18$ & $\underline{\text { Bill's }}$ & & $\begin{array}{c}\text { Billy } \\
\text { Bone's }\end{array}$ \\
\hline $2 / 18$ & mate. & Soulmate & \\
\hline $2 / 18$ & $\underline{\text { Bill }}$ & & $\begin{array}{l}\text { Billy } \\
\text { Bone }\end{array}$ \\
\hline $2 / 18$ & $\underline{\text { Bill }}$ & & $\begin{array}{l}\text { Billy } \\
\text { Bone }\end{array}$ \\
\hline $2 / 19$ & $\underline{B i l l}$ & & $\begin{array}{l}\text { Billy } \\
\text { Bone }\end{array}$ \\
\hline $2 / 19$ & $\underline{B i l l}, \underline{B i l l}$ & & $\begin{array}{l}\text { Billy } \\
\text { Bone }\end{array}$ \\
\hline $2 / 19$ & Bill, Bill, & & $\begin{array}{l}\text { Billy } \\
\text { Bone }\end{array}$ \\
\hline $2 / 19$ & $\underline{B i l l}$, & & $\begin{array}{l}\text { Billy } \\
\text { Bone }\end{array}$ \\
\hline $2 / 19$ & dear' & Deary & \\
\hline $2 / 21$ & 'Jim, & & $\begin{array}{c}\text { Jim } \\
\text { Hawkins }\end{array}$ \\
\hline
\end{tabular}


$\underline{\text { Mate }}$

$\underline{\text { Jim, }}$

Jim

Soulmate

mate,

Hawkins

$3 / 25$

$\underline{\text { Jim }}$

$3 / 26$

$\underline{\text { Jim }}$

$3 / 27$

$\underline{\text { Jim }}$

$3 / 28$

mate

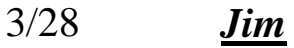

$\underline{B i l l}$

$3 / 32$

$3 / 33$

$\underline{B i l l}$

$4 / 37$

$\underline{\text { Dr. }}$.

$4 / 37$

Mrs.

4/37 $\underline{\text { Jim }}$

4/38 $\underline{\text { Jim },}$

$4 / 39$

4/41 $\underline{\text { Mrs }}$

Soulmate

4/43 dear,

Deary

Jim

Hawkins

Jim

Hawkins

Jim

Hawkins

Soulmate

Jim

Hawkins

Billy

Bone

Billy

Bone

Doctor

Mistress

Jim

Hawkins

Jim

Hawkins

Jim

Hawkins

Mistress

5/46 $\underline{\text { Bill }}$

Billy

Bone

Billy

5/47 Bill?

Bone

Billy

$5 / 47$

Bill'

Bone

Billy

5/48 $\quad \underline{\text { Bill }}$

Bones

$5 / 50$

Soulmates 


\section{Discussion}

Based on the data above, in chapter one the number of clipping that appears as much 4 words and 1 word from back formation. In chapter two the number of clipping that appears 17 words and back formation only 5 words. In chapter three the number of clipping that appears 7 words and back formation as much 3 words. In chapter four the number of clipping that appears as much 5 words and back formation as much 1 word. And in chapter five the number of clipping that appears as much 10 words and back formation only 1 word. In every chapter that clipping appears the most. Chapter four which has the most clipping, which is 17 words.

The frequency data clipping in table 1 was $79,63 \%$. The frequency data back formation in table 1 was $20,37 \%$. So it can be said that clipping words were more dominant appeared in the novel and the most frequent clipping was Bill (Billy Bone).

\section{CONCLUSION}

In this research, the researcher was conducted to analyze Treasure Island novel by Robert Louis Stevenson. Based on the result of the research, researcher conclude that novel not much use of clipping and back formation. Which means that in writing Treasure Island novel by Robert Louis Stevenson only a few words that change with removal or cutting parts of basic word with the process of clipping and back formation. It can be conclude that the number of clipping based on table 1 in Treasure Island novel by Robert Louis Stevensen is 43 words and back formation is 11 words.

\section{ACKNOWLEDGMENTS}

The researcher would like thank to Allah SWT for providing fluency, health and love in finish this journal. The researcher is also very grateful to Mrs. Ida Lisdawati S.Pd, M.Hum who has guided and assisted in finish this journal and always encourages and provides support. And the journal that was created is "The Morphological Analysis Between Back Formation and Clipping on Treasure Island Novel" which was made to meet one of the trial requirements. English Language Education, IKIP Siliwangi Bandung.

\section{REFERENCES}

Ayu Indah Maha Dewi, I. G., Artawa, K., \& Qomariana, Y. (2018). The Morphosyntax of English Deverbal Noun in The Straits Times Website. Humanis, 22(3), 742-750. 
Carlos, M., Gailea, N., \& Rima, R. (2019). A Descriptive Analysis of Slang Terms in Scarface Movie. Jurnal Makna, 5(2), 17-30.

Harared, N. (2018). Slang Created And Used In 1cak.Com Site: A Sociolinguistics Study. Humaniora, 9(2), 119-127.

Jayaputri, H. E. (2018). The Uniqueness Formation of Papuan Malay in Morphologically. JETL (Jornal Of English Language Teaching And Linguistic, 3(2), 137-150.

Kaswan, Suprijadi, D., \& Suryani, L. (2016). Research In English Language Education. Putra Praktisi Bandung.

Mainingrum, H. (2018). Morphosyntactic Analysis of African American Vernacular English in Moonlight Movie. Diponegoro University.

Mandala, I. R. (2018). If You Know What Happened in Mci. Retorika: Jurnal Ilmu Bahasa, $4(2), 132-137$.

Multazim, A., \& Nurdin, E. S. (2019). Word Formation of Photography Terminologies. Journal Of Language and Literature, 19(1), 43-54.

Nasser, M. (2018). Processes of Word Formation in English and Arabic. Journal of the College Of Education, Babylon University, Iraq, 2(3), 71-87.

Nuraeni, C. (2018). Word Formation Used In J+ Newspaper. Wanastra: Jurnal Bahasa Dan Sastra, 10(1), 31-41.

Rizki, S., \& Marlina, L. (2018). Word Formation Process in Novel Alice' S Adventures in Wonderland By Lewis Carroll and Movie Alice In. E-Journal of Language \& Literature, $7(1), 166-176$.

Rosiana, C. (2018). On-Going Morphosyntax Supplementary Material. Jurnal Dharma Pendidikan, 13(1), 35-47.

Valiyeva, N. (2019). A Paradigm Of Of The English And Azerbaijani. Scientific Council of Education Departement. 